\title{
Corporate Social Responsibility, Corporate Financial Performance and Institutional Ownership: Evidence from Malaysia
}

\author{
Mustaruddin Saleh, Rusnah Muhamad ${ }^{1}$ and Norhayah Zulkifli
}

\begin{abstract}
The purpose of this paper is to explore the relationship between corporate social responsibility (CSR) and corporate financial performance (CFP), as well as institutional ownership (IO) in the Malaysian Public Listed Companies (PLCs). Panel data analysis involving 200 companies listed on Bursa Malaysia during the period of 1999 to 2005 was conducted. The results reveal that CSR and all its dimensions are significantly positively related to CFP. It was also found that CSR and only two of its dimensions, namely, employee relations and product dimension are significant positively related to IO. The empirical findings of this study pave the way for embarking on promising and relevant future research, which is needed to substantiate and enrich the academic understanding and managerial practice of the relationship between CSR and CFP as well as IO, particularly in an emerging market such as Malaysia.
\end{abstract}

Keywords: Corporate social responsibility, corporate financial performance, institutional ownership, Malaysia.

\section{Introduction}

Efforts to encourage companies to be more involved in CSR activities and disclosure have been carried out by the Malaysian Government and the capital market authorities. In 2006, Bursa Malaysia released a CSR framework comprising a set of guidelines on CSR practices for companies. The Prime Minister of Malaysia in his 2006 budget speech encouraged companies to disclose their CSR activities (Bursa Malaysia, 2007). Various awards are introduced to give recognition to companies that are actively involved in CSR activities, including the launching of the Prime Minister's CSR Awards in 2007. However, the level

Corresponding author: Datin Dr Rusnah Muhamad is an Associate Professor at the Faculty of Business and Accountancy, University of Malaya, email: rusnah@um.edu.my. Dr Norhayah Zulkifli is a Senior Lecturer at the Faculty of Business and Accountancy, University of Malaya Dr Mustaruddin Saleh is a Senior Lecturer at the Tanjungpura University, Indonesia. 
of involvement and disclosure of CSR activities in Malaysia is still low (Bursa Malaysia, 2007; Nik Ahmad and Abdul Rahim, 2003; Williams and Pei, 1999). Thus, more effort is needed to improve the awareness of companies on CSR as well as to motivate them to be actively involved in CSR activities and to disclose these activities in the annual reports.

Substantial literature on the empirical evidence concerning the relationship between CSR and CFP as well as IO in developed markets is already in place. In Malaysia, the lack of empirical evidence on such a relationship may be one possible reason for the low CSR disclosure by companies. Thus, using CSR disclosure (CSRD) as a proxy for CSR activities, it is the aim of this paper to explore whether or not there is any association between CSR and CFP as well as IO in the context of the Malaysian PLCs.

\section{Literature Review}

The current globalization demands that companies be more involved in CSR practices (Chapple and Moon, 2005). In the period of increasing corporate financial scandals, CSR has become an important strategy for companies worldwide to improve their image as these activities can potentially create a brand image for companies and develop positive relations with stakeholders (Yoon et al., 2006). During the last two decades, the concept of CSR has been progressively rationalized and become associated with broader organizational goals, such as reputation and stakeholder management (Lee, 2008). The majority of studies and literature on CSR argue that CSR positively affects the bottom line of a company (for a review of empirical studies, see Margolis and Walsh, 2003; Orlitzky et al., 2003; Pava and Krausz, 1996).

Muirhead et al. (2002) record that as many as $90 \%$ of business managers report that their company regard CSR as the core of company principles, and 70\% assert that their companies have a business foundation that aims to promote social activities. In Malaysia, there are companies that are actively involved in various CSR practices. Prathaban (2005) record that 65 PLCs contributed RM82.1 million to various charitable community programmes, such as donation to orphanages and poor and needy people. Based on sector, the telecommunications sector has the highest contribution followed by the banking and financial services sector. In the third and fourth places are construction and property related companies and government-linked companies (GLCs). Zulkifli and Amran (2006) observe that companies usually carry out CSR activities that are in line with their business activities and are seasonal in nature following the religious/ethnic related festivals, such as Ramadan and Eid Mubarraq for the Muslims, Chinese New Year for the Chinese and Deepavali for the Indian community.

The empirical studies conducted in developed markets on the relationship between CSR and CFP are essentially of two distinct categories (see, Margolis and Walsh, 2003). The first category adopts event studies that consider the short- 
run financial impact if the company is involved in either socially or irresponsible actions. The findings are mixed. For instance, Wright and Ferris (1997) find a negative relationship, while other researchers find a positive relationship (Hall and Rieck, 1998; Posnikoff, 1997; Wright and Ferris, 1997 and Teoh et al., 1999) and no relationship is evidenced in the study conducted by Teoh et al. (1999). The second category, examines the relationship of CSR and CFP in the long-run, using accounting and market based measurements. The findings are also mixed. Various studies report a negative relationship between CSR and CFP (Moore, 2001; Vance, 1975), while other studies reveal a neutral or no relationship (Mahoney and Roberts, 2007; McWilliams and Seigel, 2000; Patten, 1990; Alexander and Buchholz, 1978). Most of the prior studies find a positive relationship between CSR and CFP (see, Simpson and Kohers, 2002; Roman et al., 1999; Graves and Waddock, 1994; Roberts, 1992; McGuire et al., 1988; Cochran and Wood, 1984; Anderson and Frankle, 1980; Belkaoui, 1976; Bowman and Haire, 1975).

From the theoretical perspective, Spicer (1978) argues that institutional investors consider investing in the low socially responsible companies as a risky investment. This risk emerges from the possibility of damaging sanctions that result in legislative or regulatory action, decisions of a court, or consumer relations. Thus, investing in companies that are socially responsible may reduce the above risk. Therefore, managers should take a cue from this theoretical perspective to invest in CSR activities (Cox et al., 2004). The empirical studies of the relationship between CSR and IO reveal a positive relationship (Cox et al., 2004; Johnson and Greening, 1999; Waddock and Graves, 1997; Graves and Waddock, 1994) and no relationship (Mahoney and Roberts, 2007).

\section{Methodology}

The data for this study are gathered from the annual reports of 200 large companies representing 70 per cent of the market capitalization of Bursa Malaysia for the period of 1999 to 2005, which is consistent with prior studies (Thompson and Zakaria, 2004; Guthrie and Parker, 1990). The annual reports of companies were chosen based on two main reasons. First, the annual report is the most important source of corporate reporting (Jenkins and Yakovlena, 2005; Al-Tuwaijri et al., 2004; and Tilt, 1994). Second, in Malaysia, annual reports of listed companies are the most accessible source of information, either in hard copy or electronic publications (Christopher et al., 1997; Wiseman, 1982).

There are two main variables, namely, dependent variables, comprising CFP and IO, and independent variables, which include CSR and the dimensions of CSR, as well as a set of control variables. This paper utilizes one-year time lag, for example, the year 2000 data are used for the dependent variable and the year 1999 data for independent variables (Mahoney and Roberts, 2007; Waddock and Graves, 1997). Three alternative measurements are used to measure CFP, namely, accounting-based performance measurements in the form of return on 
assets (ROA); market-based performance measurements in the form of stock market return $\left(\mathrm{R}_{i}\right)$; and Tobin's $q$ ratio $(q)$, which represents the market value of total equity and debt. IO is represented by the number of institutional investors holding company shares (NUMBIO) and the percentage of outstanding shares held by institutional investors (PERCIO). The independent variables include the main independent variables and the control variables. The main independent variables are CSR and its four dimensions of CSR, namely, employee relations, community involvement, product and environment. The control variables consist of SIZE, LEVERAGE (LEV), BETA, SALES, ASSET TURNOVER RATIO (ATR), and EARNINGS PER SHARE (EPS).

In this study CSRD represents the involvement of companies in CSR activities, which are communicated to their stakeholders via the annual reports of companies. We assign value for each item disclosed (see, for example, Al-Tuwaijri et al., 2004; Hughes et al., 2001) based on the type of disclosure, as follows: (1) quantitative disclosure - 3; (2) qualitative specific disclosure - 2; (3) qualitative disclosure -1 ; (4) no disclosure -0 . The total scores for CSRD are obtained by summing all the sub scores obtained for the four CSR dimensions examined.

In this study, the generalized least squares (GLS) method is used. The model specifications are given as follows:

$$
\begin{aligned}
& \mathrm{y}_{\mathrm{it}}=\mathrm{a}_{\mathrm{i}}+\mathrm{x}_{\mathrm{i}} \beta+v_{\mathrm{i}}+\mu_{\mathrm{it}} \\
& \gamma_{\mathrm{it}}=\alpha_{\mathrm{i}}+\mathrm{x}_{\mathrm{i}} \beta+v_{\mathrm{i}}+\mu_{\mathrm{it}}
\end{aligned}
$$

Where $\mathrm{y}$ is the dependent variable (i.e. CFP measures, namely, ROA, Stock Return (Ri), and Tobin's q ratio (Q); $\gamma$ is the dependent variable of the $\mathrm{IO}$, represented by the number of institutional investors that hold shares of companies (NUMBIO) and the percentage of shares owned by institutional investors (PERCIO). The independent variables are represented by x (i.e. CSR and the four dimensions of CSR, namely, employee relation disclosure score (EMPD), community involvement disclosure score (COMD), product disclosure score (PROD), environment disclosure score (ENVD), and the control variables including firms' systematic risk (BETA), leverage (LEV), logSize (LSIZE), log sales (LSALES), asset turnover (ATR), and earnings per share (EPS); $\beta$ is the coefficient of the independent variables; $\mu$ represents the error term; $v$ is the unobserved firm effect; $i$ indicates a firm number; and $t$ represents time. The error term $\left(\mu_{i t}\right)$ for the random effects model using equation (1) and (2) can be defined as

$$
\mu_{i t}=\mathrm{e}_{i}+v_{i t}
$$

Where $\mathrm{e}_{i}$ is the cross-section error component and $v_{i t}$, combines the crosssection and time series error component. The Hausman test is employed to evaluate the level of significance between estimators in deciding the more precise model, either the fixed effects or the random effects model. 


\section{Findings}

Table 1 reports the results of descriptive statistics and Pearson's correlation matrix. CFP is measured by ROA, Ri and Tobin's $q$ ratio. The mean value and standard deviation for ROA are 4.48 per cent and 16.62 per cent, respectively. This result indicates that, on average, the profitability of companies for the fiscal year is 4.48 per cent. The mean and standard deviation value of share return are 8.59 per cent and 22.46 per cent, respectively, implying that the average of share returns during the period under study is 8.59 per cent and the variance of shares returns among companies is 22.46 per cent. These results indicate that, on average, investors are making profits from their investment in the shares of the companies under observation.

Tobin's $q$ ratio is measured by the market value of a company divided by the replacement cost of its assets (Lindenberg and Ross, 1981). At equilibrium condition, the value of Tobin's $q$ ratio is around 1. If Tobin's $q$ ratio is greater than 1, the investors have high incentive to invest and vice versa (Kim et al., 1993). The mean value for the Tobin's $q$ ratio is 0.96 and the standard deviation is 0.95 indicating that, on average, companies only have 0.96 of resources to replace their assets. This result reveals that the market value of companies is below 1.0, implying that the cost to replace the assets is larger than the share values of companies observed.

Table 1 depicts that the mean score for the number of institutional investors is 13 . On average, 51.73 per cent of company shares are held by institutional investors. The mean score for CSRD is 1.36 and the average systematic risk represented by betas is 1.10 and the standard deviation is 0.42 per cent. The average amount of assets in ringgit for companies in this data set is RM1.79 billion and the total sales are RM1.25 billion. The average return on assets (ROA) is RM0.04 and earnings per share is RM25.00. When IO is represented by NUMBIO, five variables, namely, PERCIO, CSRD, LEV, LSIZE and LSALES are found to have a significant positive correlation with NUMBIO. On the other hand, when PERCIO is used, five variables comprising CSRD, LSIZE, LSALES, ATR and EPS are found to be significantly correlated to PERCIO. It was found that PERCIO is positively correlated to CSRD, LSIZE and LSALES; however it is negatively related to ATR and EPS. The significant positive correlation established between CSR and the two alternative measures of IO (i.e. NUMBIO and PERCIO) indicates that CSR activities are positively related to the level of shareholdings by the institutional investors.

Table 2 shows results of hypothesis testing between CSR and its dimension with CFP using GLS with the fixed effects model (FEM). Generally, the outcomes of the $t$-test are significant, at least at 10 per cent. The results indicate that CFP is clearly explained by CSR and the set of explanatory variables, and the overall estimation is good ranging between 77.14 per cent and 98.35 per cent.

The results indicate that each company has its own characteristics differing between small and big companies and between companies that have more debt and 
Table 1: Descriptive Statistic and Pearson's Correlation Matrix of Variables

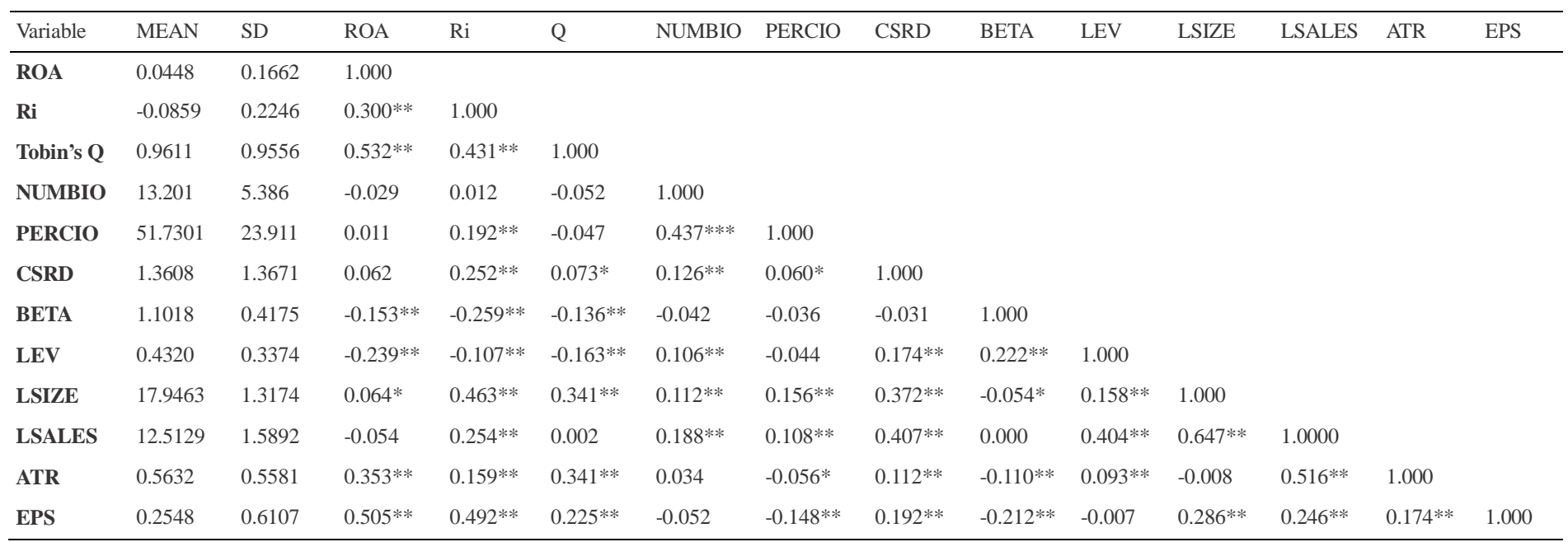

Notes: **Correlation is significant at the 0.01 level (2-tailed), * Correlation is significant at the 0.05 level (2-tailed). 
less debt. Bigger companies are more highly leveraged than small companies and companies with high leverage assume more risk than lower leverage companies. Therefore, we can conclude that leverage (LEV) may have either a negative or positive impact on the financial performance of companies. The high leverage companies need financial resources to pay the cost of debts and repay, resulting in a negative impact on CFP, and, as at a certain level, the cost of debt is usually less expensive than the cost of equity and acquiring debts is relatively easier, it leads to a positive impact on CFP.

Table 2: The relationship between CSR and CFP

\begin{tabular}{|c|c|c|c|c|c|c|}
\hline \multirow[b]{2}{*}{ Variables } & \multicolumn{3}{|l|}{ CSR on CFP } & \multicolumn{3}{|c|}{ Dimension of CSR on CFP } \\
\hline & $\begin{array}{l}\text { Model 1.1: } \\
\text { (ROA) }\end{array}$ & $\begin{array}{l}\text { Model 1.2: } \\
(\mathrm{R} i) \text { : }\end{array}$ & $\begin{array}{l}\text { Model 1.3: } \\
\text { Tobin's Q }\end{array}$ & $\begin{array}{l}\text { Model 1.1: } \\
\text { (ROA) }\end{array}$ & $\begin{array}{l}\text { Model 1.2: } \\
(\mathrm{R} i)\end{array}$ & $\begin{array}{l}\text { Model 1.3: } \\
\text { Tobin's Q }\end{array}$ \\
\hline \multirow[t]{2}{*}{$\mathrm{C}$} & -0.1161 & $-1.5801 * * *$ & $0.8732 * * *$ & -0.0097 & $-1.6142 * * *$ & $06157 * * *$ \\
\hline & $(0.0229)$ & $(03132)$ & $(02479)$ & $(0.0314)$ & $(0.3455)$ & $(0.2404)$ \\
\hline \multirow[t]{2}{*}{ CSRD } & $0.0007 * * *$ & $0.0047^{* * * *}$ & $0.0008^{* * *}$ & & & \\
\hline & $(5.88 \mathrm{E}-05)$ & $(0.0007)$ & $(0.0002)$ & & & \\
\hline \multirow[t]{2}{*}{ EMPLD } & - & - & - & $0.0007 * * *$ & $0.0088^{* * *}$ & $0.0018 * * *$ \\
\hline & & & & $(0.0001)$ & $(0.0021)$ & $(0.0004)$ \\
\hline \multirow[t]{2}{*}{ COMD } & - & - & - & $0.0014^{* * * *}$ & $0.0133 * * *$ & $-0.0148 * * *$ \\
\hline & & & & $(0.0001)$ & $(0.0020)$ & $(0.0004)$ \\
\hline \multirow[t]{2}{*}{ PROD } & - & - & - & $0.0003^{* * * *}$ & $-0.0177 * * *$ & $0.0153 * * *$ \\
\hline & & & & $(0.0001)$ & $(0.0020)$ & $(0.0004)$ \\
\hline \multirow[t]{2}{*}{ ENVD } & - & - & - & $0.0010^{* * * *}$ & $0.0174 * * *$ & $-0.0134 * * *$ \\
\hline & & & & $(0.0001)$ & $(0.0016)$ & $(0.0008)$ \\
\hline \multirow[t]{2}{*}{ BETA } & $0.0030^{* * *}$ & $0.0931^{* * *}$ & $0.0442 * * *$ & $0.0025^{* * * *}$ & $0.0968 * * *$ & $0.0400 * * *$ \\
\hline & $(0.0003)$ & $(0.0134)$ & $(0.0010)$ & $(0.0003)$ & $(0.0129)$ & 0.0011 \\
\hline \multirow[t]{2}{*}{ LEV } & $-0.0563 * * *$ & $0.0895^{*}$ & $0.1813 * * *$ & $-0.0580 * * *$ & 0.0727 & $0.1883 * * *$ \\
\hline & $(0.0055)$ & $(0.0515)$ & $(0.0010)$ & $(0.0056)$ & $(0.0467)$ & $(0.0005)$ \\
\hline \multirow[t]{2}{*}{ LSIZE } & $0.0035^{* * *}$ & 4.17E-08)*** & $1.01 \mathrm{E}-07 * * *$ & $0.0033^{* * *}$ & $4.95 \mathrm{E}-08 * * *$ & $9.94 \mathrm{E}-08 * * *$ \\
\hline & $(0.0003)$ & (2.05E-09) & $(4.62 \mathrm{E}-10)$ & $(0.0003)$ & (2.91E-09) & $(5.37 \mathrm{E}-10)$ \\
\hline \multirow[t]{2}{*}{ LSALES } & $-7.81 \mathrm{E}-09^{* * * *}$ & $-8.66 \mathrm{E}-09^{* *}$ & $-3.64 \mathrm{E}-02 * * *$ & $-7.18 \mathrm{E}-09 * * *$ & $-8.61 \mathrm{E}-09^{*}$ & $-3.85 \mathrm{E}-02 * * *$ \\
\hline & $(2.97 \mathrm{E}-10)$ & $(4.35 \mathrm{E}-09)$ & $(8.16 \mathrm{E}-04)$ & $(2.69 \mathrm{E}-10)$ & (4.57E-09) & $(8.53 \mathrm{E}-04)$ \\
\hline \multirow[t]{2}{*}{ ATR } & $0.0216^{* * *}$ & $0.0698 * * *$ & $0.1272 * * *$ & $0.0211 * * *$ & $0.0625 * * *$ & $0.1360 * * *$ \\
\hline & $(0.0011)$ & $(0.0095)$ & $(0.0036)$ & $(0.0011)$ & $(0.0090)$ & $(0.0035)$ \\
\hline \multirow[t]{2}{*}{ EPS } & $0.0007 * * *$ & $0.0010^{* * * *}$ & 7.94E-05*** & $0.0007^{* * * *}$ & $0.0007 * * *$ & $9.03 \mathrm{E}-05^{* * * *}$ \\
\hline & $(1.92 \mathrm{E}-05)$ & $(0.0001)$ & (8.96E-06) & $(1.90 \mathrm{E}-05)$ & (9.96E-05) & (8.89E-06) \\
\hline Adjusted $R^{2}$ & 0.7714 & 0.9335 & 0.9121 & 0.7635 & 0.9379 & 0.9173 \\
\hline$F$-statistic & $23.5874 * * *$ & $400.8966^{* * * *}$ & 109.8469 **** & $22.3002^{* * * *}$ & $538.675 * * *$ & $119.7289 * * *$ \\
\hline DW-statistic & 2.0002 & 1.6337 & 1.7498 & 1.9989 & 1.6459 & 1.7607 \\
\hline Hausman test & $157.4781 * * *$ & $87.8979 * * *$ & $7.8783^{* * *}$ & 219.869 **** & $149.4923^{* *}$ & $5.2848 * *$ \\
\hline $\begin{array}{l}\text { Type of Panel } \\
\text { Data }\end{array}$ & Fixed & Fixed & Fixed & Fixed & Fixed & Fixed \\
\hline
\end{tabular}

Notes: (i) Figures in parentheses are standard errors robust to heteroscedasticity

(ii) DW statistic is Durbin-Watson d test for autocorrelation .

(iii) $* \mathrm{p}<0.10$, ** $\mathrm{p}<0.05$, and $* * * \mathrm{p}<0.01$

(iv) Number of observations is 1102 
Table 2 also reports the results for the four dimensions of CSR. Overall, all dimensions are significantly related to CFP. These results support the hypotheses for CSR dimensions. Therefore, we can conclude that there is a significant positive relationship between CSR and CFP. The results support the proposal made by Yoon et al. (2006), which suggest that these activities create a brand image for a company that can develop positive public relations with stakeholders, such as creating customer loyalty and investor trust that result in improved earnings and market value for a company. Overall, the significantly positive relationship between the CSR dimensions and CFP indicate that stakeholders react positively towards the involvement of companies in the specific dimension of CSR. For instance EMPD is significantly positively related to CFP implying that CFP can be improved if managers have knowledge and good relations with employees. Thus, suggesting that managers should find ways to improve employee relations, which may result in improved productivity, and, hence, may lead to better financial performance for the company. COMD is significantly positively related to CFP, which indicates that stakeholders do not react negatively towards companies spending for the betterment of society. This result implies that Malaysian managers may use the community enhancement programme to strategically position their company in the competitive market. The significant positive relationship established between PROD and CFP signifies that companies need to give emphasis to the continuous improvement of their products, such as having in place a systematic and organised research and development programme to ensure that the quality and safety of products/services are continuously enhanced. ENVD is found to be significantly positively related to CFP showing that there is a strong link between environmental management and CFP. Therefore, companies may consider disclosing information on environmental conservation and protection as part of a strategy to improve their financial performance (Bewley and Li, 2000).

Table 3 provides the results for the hypothesis testing on the relationship between CSR and its dimensions with IO. Overall, the outcomes of the $t$-tests are significant at the 1 per cent level ( $F$ test is statistically significant at $\mathrm{p}<0.01)$. Therefore, we can conclude that there is a strong association between CSR and its dimensions with IO.

These results are consistent with the point of view that institutional investors are concerned with how managers manage the social issues in their company, as various studies show that companies with a high rating in social performance are more attractive to institutional investors (see for example, Mahoney and Roberts, 2007; Graves and Waddock, 1994) and that institutional investors use CSR information in their shareholding decision (e.g. Mahoney and Roberts, 2007; Coffey and Fryxell, 1991; Teoh and Shiu, 1990). The relationship between the CSR dimensions and IO, as reflected in Table 3, show mixed results. Only one dimension of CSR, namely, EMPD is significantly positively related to IO in both models, while PROD is only found to be significantly positively related to IO in Model 2.1. However, we found a significant negative relationship in COMD 
Table 3: The relationship between CSR and IO using Unbalanced Panel Data

\begin{tabular}{|c|c|c|c|c|}
\hline \multirow[b]{2}{*}{ Variable } & \multicolumn{2}{|l|}{ CSR on IO } & \multicolumn{2}{|c|}{ Dimensions of CSR on IO } \\
\hline & $\begin{array}{l}\text { Model 2.1: } \\
\text { (NUMBIO) }\end{array}$ & $\begin{array}{l}\text { Model 2.2: } \\
\text { (PERCIO) }\end{array}$ & $\begin{array}{l}\text { Model 2.1: } \\
\text { (NUMBIO) }\end{array}$ & $\begin{array}{l}\text { Model 2.2: } \\
\text { (PERCIO) }\end{array}$ \\
\hline \multirow[t]{2}{*}{$\mathrm{C}$} & $11.8114 *$ & $43.5669 * * *$ & $11.7307 * * * *$ & $43.0823 * * *$ \\
\hline & $(0.0872)$ & $(1.1787)$ & $(1.6876)$ & $(1.1684)$ \\
\hline \multirow[t]{2}{*}{ CSRD } & 0.0689 & $0.1468 * * *$ & & \\
\hline & $(0.0560)$ & $(0.0478)$ & & \\
\hline \multirow[t]{2}{*}{ EMPLD } & & & $0.6684^{* * * *}$ & $0.3903 * * *$ \\
\hline & & & $(0.1656)$ & $(0.1446)$ \\
\hline \multirow[t]{2}{*}{ COMD } & & & $-0.2745^{* * *}$ & $-0.2627 * *$ \\
\hline & & & $(0.1125)$ & $(0.1506)$ \\
\hline \multirow[t]{2}{*}{ PROD } & & & $0.2103^{* * *}$ & -0.0480 \\
\hline & & & $(0.0928)$ & $(0.1050)$ \\
\hline \multirow[t]{2}{*}{ ENVD } & & & -0.0800 & $-0.1819 * * *$ \\
\hline & & & $(0.0837)$ & $(0.0516)$ \\
\hline \multirow[t]{2}{*}{$\mathrm{Ri}$} & $-0.3242 *$ & $-0.3243 * * *$ & -0.2507 & $-0.4662 * * *$ \\
\hline & $(0.1653)$ & $(0.0965)$ & $(0.1649)$ & $(0.1350)$ \\
\hline \multirow[t]{2}{*}{ BETA } & $-0.5313^{* * *}$ & $-1.0228 * * *$ & $-0.4838^{* * *}$ & $-0.9560^{* * * *}$ \\
\hline & $(0.1437)$ & $(0.0641)$ & $(0.1220)$ & $(0.0887)$ \\
\hline \multirow[t]{2}{*}{ LEV } & $-0.8524 * * *$ & 0.3447 & $-0.7296^{* * *}$ & $0.2746^{* *}$ \\
\hline & $(0.1839)$ & $(0.0641)$ & $(0.1855)$ & $(0.1209)$ \\
\hline \multirow[t]{2}{*}{ LSIZE } & $0.6233^{* * * *}$ & 0.0738 & $0.4889^{* * * *}$ & $0.7989 * * *$ \\
\hline & $(0.2543)$ & $(0.0625)$ & $(0.1882)$ & $(0.1302)$ \\
\hline \multirow[t]{2}{*}{ LSALES } & $0.5101^{* *}$ & -0.0509 & $0.4889^{* *}$ & $-0.8884 * * *$ \\
\hline & $(0.2543)$ & $(0.1214)$ & $(0.1882)$ & $(0.2780)$ \\
\hline \multirow[t]{2}{*}{ ATR } & $-0.1281^{*}$ & 0.0582 & -0.1375 & $0.4249 * * *$ \\
\hline & $(0.0757)$ & $(0.0789)$ & $(0.0885)$ & $(0.1480)$ \\
\hline \multirow[t]{2}{*}{ EPS } & $-4.52 \mathrm{E}-05^{* *}$ & $-0.0001 * * *$ & $-4.12 \mathrm{E}-05^{* *}$ & $-0.0002 * * *$ \\
\hline & $(1.96 \mathrm{E}-05)$ & $(4.54 \mathrm{E}-05)$ & $(1.89 \mathrm{E}-05)$ & $(0.0000)$ \\
\hline Adjusted $R^{2}$ & 0.9240 & 0.9361 & 0.9243 & 0.9359 \\
\hline$F$-Statistic & $82.7566^{* * * *}$ & $1755.58 * * *$ & $81.8540^{* * * *}$ & $1626.20 * * *$ \\
\hline DW-Stat & 1.2261 & 1.3666 & 1.2336 & 1.3558 \\
\hline Hausman Test & $23.8471 * * *$ & $30.1491 * * *$ & $87.77 * * *$ & $6.1993^{* *}$ \\
\hline Type of Panel Data & Fixed & Fixed & Fixed & Fixed \\
\hline
\end{tabular}

Notes: (i) Figures in parentheses are standard errors robust to heteroscedasticity,

(ii) DW statistic is Durbin-Watson d test for autocorrelation,

(iii) $* \mathrm{p}<0.10, * * \mathrm{p}<0.05$, and $* * * \mathrm{p}<0.01$

(iv) Number of observations is 1095.

(in both models) and ENVD (only in Model 2.2). Therefore, we can conclude that the preceding discussion partially supports $\mathrm{H} 2$ and is consistent with the 
findings established in studies by Cox et al. (2004) for EMPD, and Mahoney and Roberts (2007) for PROD. Therefore, confirming the assertion made by Teoh and Shiu, (1990) that institutional investors are not totally opposed to companies' involvement in social activities. The negative relationships of both COMD and ENVD may possibly indicate that institutional investors perceived that the investment in both dimensions requires a significant amount of financial resources, and, thus, has a negative impact on the cash flow of companies. The higher expenditure allocated to both community involvement and environment may place companies at an economic disadvantage compared to other companies that are less socially responsible (Balabanis et al., 1998). These findings indicate that institutional investors in Malaysia are mainly profit orientated and shorttermism rather than focusing on the long term sustainability of a company.

\section{Summary and Conclusions}

The main aim of this study was to explore the relationship between CSR and CFP as well as IO in Malaysian PLCs. The results of longitudinal data analysis found that CSR is significantly positively related to CFP and IO. It was also found that all four dimensions of CSR are significantly positively related to CFP, which signifies that companies may strategically use the investment in CSR activities to improve the financial performance of companies. The significant positive relationship between CSR and IO indicates that institutional investors are considering the social performance of companies in making investment decisions, particularly for ethical investors, such as Shariah Compliant Funds, Unit Trusts and Investment Trusts, which emphasise the social responsibility of companies.

Future research may be conducted to include a larger sample size according to the category of the company. It will be useful to examine the motives and perceptions of managers in disclosing CSR by conducting in-depth interviews or employing the questionnaire survey method. The same study could also be conducted in other emerging markets to determine whether the same general relationship exists.

\section{References}

Alexander, G. J. and Buchholz, R. A. (1978) .Corporate social responsibility and stock market performance. Academy of Management Journal, vol. 21, pp. 479-486.

Al-Tuwaijri, S. A., Christensen, T. E. and Hughes II, K. E.(2004). The relations among environmental disclosure, environmental performance, and economic performance: A simultaneous equations approach. Accounting, Organizations and Society, vol. 29, pp. 447-471.

Anderson, J. C. and Frankle, A. C. (1980). Voluntary social reporting: An isobeta portfolio analysis. The Accounting Review, vol 55, no. 3, pp. 467-779. 
Balabanis, G., Philip. H. G. and Lyall, J. (1998). Corporate social responsibility and economic performance in the top British companies: Are they linked?. European Business Review, vol. 98 no. 1, pp. 25-44.

Belkaoui, A. (1976). The impact of the disclosure of the environmental effects of organizational behavior on the market. Financial Management, vol. 5 no. 4, pp. 26-31.

Bewley, K., and Li, Y. (2000). Disclosure of environmental information by Canadian manufacturing companies: A voluntary disclosure perspective. Advances in Environmental Accounting and Management, vol. 1, pp. 201226.

Bowman, E. H. and Haire, M. A. (1975). A strategic posture toward corporate social responsibility. California Management Review, vol. 18, no.2, pp. 49-58.

Bursa Malaysia. (2007). Corporate Social Responsibility in Malaysian PLCs, An executive summary, 2007 Status Report. available at: http://www.klse.com. my/ website/ bm/about us/the organization/csr /downloaded/ csr booklet. pdf (accessed 12 July 2008).

Chapple, W. and Moon, J.(2005). Corporate social responsibility (CSR) in Asia. Business and Society, vol. 44, no.4, pp. 415-441.

Christopher. T, Hutomo, Y. B. S. and Monroe, G. (1997). Voluntary environmental disclosure by Australian listed mineral mining companies: an application of stakeholder theory. The International Journal of Accounting and Business Society, vol. 5, no.1, pp. 42-65.

Cochran, P. L. and Wood, R. A. (1984). Corporate social responsibility and financial performance. Academy of Management Journal, Vol. 27 No. 1, pp. $42-56$.

Coffey, B. S. and Fryxell, G. E. (1991). Institutional ownership of stock and dimensions of corporate social performance: an empirical examination. Journal of Business Ethics, vol. 10, no. 6, pp. 437-444.

Cox, P., Brammer, S. and Millington, A. (2004). An empirical examination of institutional investor preferences for corporate social performance. Journal of Business Ethics, vol. 52, no. 1, pp. 27-42.

Graves, S. B. and Waddock, S. A. (1994). Institutional ownership and corporate social performance. Academy of Management Journal, vol. 37, no. 4, pp. 1034-1046.

Hall, P. L. and Rieck, R. (1998). The effect of positive corporate social actions on shareholder wealth. Journal of Financial and Strategic Decisions, vol. 11, no. 2, pp. 83-89.

Jenkins, H. and Yakovlena, N. (2005). Corporate social responsibility in the mining industry: exploring trends in social and environmental disclosure. Journal of Cleaner Production, pp. 1-14.

Johnson, R. A. and Greening, D. W. (1999). The effects of corporate governance and institutional ownership types on corporate social performance. Academy of Management Journal, vol. 42, no. 5, pp. 564-576. 
Kim, K., Henderson, G. and Garrison, S. (1993). Examination of Tobin's $q$ for takeover firms. Quarterly Journal of Business and Economics, vol. 32, no. 1, pp. 3-26.

Lee, M. P. (2008). A Review of the theories of corporate social responsibility: its evolutionary path and the road ahead. International Journal of Management Reviews, vol. 10, no. 1, pp. 53-73.

Lindenberg, E. and Ross, S. (1981). Tobin's $q$ ratio and industrial organization . Journal of Business, vol. 54, no. 1, pp. 1-32.

Mahoney, L. and Roberts, R. W. (2007). Corporate social performance, and financial performance and institutional ownership in Canadian firms. Accounting Forum, vol. 31, pp. 233-253.

Margolis, J. D. and Walsh, J. P. (2003). Misery loves companies: rethinking social initiatives by business. Administrative Science Quarterly, vol. 48, pp. 655-689.

McGuire, J., Sundgren, A. and Schneeweis, T. (1988). Corporate social responsibility and firm financial performance. Academy of Management Journal, vol. 31, no. 4, pp. 854-872.

McWilliams, A. and Siegel, D. (2000). Corporate Social Responsibility and Financial Performance: correlation or misspecification?. Strategic Management Journal, vol. 21, pp. 603-609.

Moore, G. (2001). Corporate social and financial performance: an investigation in the U.K. Supermarket industry. Journal of Business Ethics, vol. 34, no. 3/4, pp. 299-316.

Muirhead, S. A., Bennett, C. J., Berenbeim, R. E., Kao, A. and Vidal, D. J. (2002). Corporate Citizenship in the New Century: Accountability, Transparency, and Global Stakeholder Engagement, The Conference Board, New York.

Nik Ahmad, N. Z. and Abdul Rahim, N. L. A. (2003). Awareness of the concepts of corporate social responsibility among Malaysian managers in selected public listed companies. paper presented at the $7^{\text {th }}$ International Conference on Global Business and Economic development, Plaza Athanee Hotel, Bangkok, Thailand, 8-11 January.

Orlitzky, M., Schmidt, F. L., and Rynes, S. L. (2003). Corporate Social and Financial Performance: A Meta-Analysis. Organization Studies, vol. 24, no. 3, pp. 403-441.

Patten, D. M. (1990). The Market reaction to social responsibility disclosures: the case of the Sullivan principles signings. Accounting, Organization and Society, vol. 15, pp. 575-587.

Pava, M. L. and Krausz, J. (1996). The association between corporate socialresponsibility and financial performance - the paradox of social cost. Journal of Business Ethics, vol. 15, no. 3, pp. 321-357.

Posnikoff, J. F. (1997). Disinvestment from South Africa: They did well by doing good. Contemporary Economic Policy, vol. 15, no. 1, pp. 76-86. 
Prathaban, V. (2005). Big earners, small givers?. Malaysian Business, 16 September.

Robert, R. W. (1992). Determinants of corporate social responsibility disclosure: an application of stakeholder theory. Accounting, Organisations and Society, pp. 595-612.

Roman, R. M., Hayibor, S. and Agle, B. R. (1999). The relationship between social and financial performance: repainting a portrait. Business and Society, vol. 38, pp. 109-118.

Simpson, W. G. and Kohers, T. (2002). The link between corporate social and financial performance: Evidence from the banking industry. Journal of Business Ethics, vol. 35, no. 2, pp. 97-109.

Spicer, B. H. (1978). Investors, corporate social performance and information disclosure: An empirical paper. Accounting Review, vol. 53, pp. 94-111.

Teoh, H. Y. and Shiu, G. Y. (1990). Attitudes towards corporate social responsibility and perceived importance of social responsibility information characteristics in a decision context. Journal of Business Ethics, vol. 9, no. 1, pp. 71-77.

Teoh, S. H., Welch, I. and Wazzan, C. P. (1999). The effect of socially activist investment policies on the financial markets: Evidence from the South African Boycott. Journal of Business, vol. 72, no. 1, pp. 36-89.

Tilt, C. A. (1994). The influence of external pressure groups on corporate social disclosure: some empirical evidence. Accounting, Auditing \& Accountability Journal, vol. 7, no. 4, pp. 47-72.

Vance, S. C. (1975). "Are socially responsible corporations good investment risk?", Management Review, vol. 64, pp. 18-24.

Waddock, S. A. and Graves, S. B. (1997). The corporate social performancefinancial performance link. Strategic Management Journal, vol. 18, no. 4, pp. 303-319.

Williams, S. M. and Pei, C. H. W. (1999). Corporate social disclosures by listed companies on their web sites: An international comparison. The International Journal of Accounting, vol. 34, no. 3, pp. 389-419.

Wiseman J. (1982). An evaluation of environmental disclosures made in corporate annual reports. Accounting, Organizations and Society, vol. 7, no. 1, pp. 53-63.

Wright, P. and Ferris, S. P. (1997). Agency conflict and corporate strategy: Effect of divestment on corporate value. Strategic Management Journal, vol. 18, no. 1 , pp. 77-83.

Yoon, Y., Giirhan-Canli, Z. and Schwarz, N. (2006). The Effect of Corporate Social Responsibility (CSR) Activities on Companies with Bad Reputations. Journal of Consumer Psychology, vol. 16, no. 4, pp. 377-390.

Zulkifli, N. and Amran, A. (2006). Realising Corporate Social Responsibility in Malaysia: View from the Accounting Profession, Journal of Corporate Citizenship, vol. 24, pp. 110-114. 